\title{
Diabetes Mellituslu Hastalarda Podolojik Açıdan Ayak Değerlendirmesi
}

\author{
Ülker ÖZDEMİR ${ }^{1 \oplus \bowtie, ~ B a n u ~ K U R B A N ~}{ }^{1} \oplus$, Taner BAYRAKTAROĞLU ${ }^{2}$ \\ ${ }^{1}$ Zonguldak Bülent Ecevit Üniversitesi, Sağlık Bilimleri Enstitüsü, Podoloji Yüksek Lisansı, Zonguldak \\ ${ }^{2}$ Zonguldak Bülent Ecevit Üniversitesi, Tıp Fakültesi, Endokrinoloji ve Metabolizma Hastalıkları Bilim Dalı, Zonguldak
}

Bu makaleye yapılacak atıf: Özdemir Ü, Kurban B, Bayraktaroğlu T. Diabetes Mellituslu Hastalarda Podolojik Açıdan Ayak Değerlendirmesi. Türk Diyab Obez 2019;1: 51-62.

\begin{abstract}
ÖZET
Diabetes mellitusun önemli ve sık görülen komplikasyonlarından birisi diyabetik ayaktır. Aynı zamanda diyabetiklerin en sık hastaneye yatış nedenlerinden biridir. Diyabetik ayak (DA) yaralarının hem hasta hem de sağılı bakım sistemleri için ciddi sonuçları vardır. Diyabetli hastalarda ayak ülserlerinin ortaya çıkmasını engellemek veya var olan bir ülsere erken müdahale ekstremite ampütasyonlarını önlemektedir. Bu da iyi bir ayak değerlendirmesiyle mümkündür. Bu derlemede güncel tıbbi yaklaşımda rehberler doğrultusunda ayağın dermatolojik, nörolojik, vasküler ve biyomekanik değerlendirmesi sunulmaktadır.
\end{abstract}

Anahtar Sözcïkler: Diabetes mellitus, Diyabetik ayak, Ayak değerlendirmesi, Podoloji

\section{Podologic Evaluation of Foot in Patients with Diabetes Mellitus}

\begin{abstract}
Diabetic foot is one of the most important and frequent complications of diabetes mellitus.It is also one of the most common causes of hospitalization in diabetics. Diabetic foot wounds have serious consequences for both patients and health care systems. Prevention of foot ulcers in patients with diabetes or early intervention to an existing ulcer prevents limb amputations. This is possible with a good foot evaluation.In this review, dermatological, neurological, vascular and biomechanical evaluation of the foot is presented in accordance with the guidelines in the current medical approach.
\end{abstract}

Key Words: Diabetes mellitus, Diabetic foot, Foot evaluation, Podology

\section{GíRiş}

Diyabetik ayak enfeksiyonları, diabetes mellitusun sık görülen komplikasyonlarından biridir. Aynı zamanda diyabetik hastaların en sık hastaneye yatış nedenlerinden biridir. Diyabetik ayak enfeksiyonlarının ortaya çıkışında en önemli hazırlayıcı faktörleri periferik damar hastalı̆̆ı ve nöropatidir. Diyabetin ayak komplikasyonu, dünyada her 30 saniyede bir ayak kaybına neden olmaktadır (1-6). Diyabetik hastaların yaklaşık \%50'si tüm yaşamları boyunca diyabetik ayak gelişme riski altındadır ve diyabetik ayak diyabetin kronik komplikasyonları arasında yaşam kalitesini en yüksek oranda etkileyen bir tablodur $(3,4)$.

Diyabetik ayak yaraları, hem hasta hem de sağlık bakım sistemleri için ciddi sonuçları bulunmaktadır. Ayak ülserleri, diabetes mellitusun en maliyetli ve önlenebilir bir komplikasyonudur (5-12). Mortaliteye, morbiditeye, iş gücü kaybına, sakatlıklara, başkalarına bağımlığa, psikososyal travmaya ve sağlık bakım maliyetinin artmasına yol açar. Diyabetik ayak ve infeksiyonları, hastanın ayak bakımının sağlanması ve diyabetinin kontrol altına alınmasıyla çoğu kez önlenebilir. Çoğu kez de oluşan bir yarayı erkenden saptayarak, iyileştirerek ya da bir infeksiyonu erken tedavi ile ağır sonuçların önüne geçilebilir (9-15).

ORCID: Ülker Özdemir / 0000-0002-5332-3423, Banu Kurban / 0000-0003-4684-5255, Taner Bayraktaroğlu / 0000-0003-3159-6663 
Diyabetik birey sayısındaki artış ve çoğunun obez olması, ayak sağllğının ve korunmanın ne denli önemli olduğunun bir göstergesidir. Diyabetli hastalarda ayak ülserlerinin ortaya çıkmasını engellemek veya var olan bir ülsere erken müdahale etmek ekstremite ampütasyonlarını önlemektedir. $\mathrm{Bu}$ da iyi bir ayak muayenesinin dermatolojik, nörolojik, vasküler ve biyomekanik değerlendirmesi ile mümkündür (15-20). Yüksek riskli ayak sorunlarını tanımlamak ve saptamak gerekmektedir. Diyabeti olan hastalar her muayenede çorapları ve ayakkabıları çıkartılarak kontrol edilmelidir. Ayrıca en az yılda bir kez kapsamlı olarak özel ayak muayenesi yapılmalıdır. Bu muayene sırasında deri bütünlüğü, damar yapısı, koruyucu duyu, ayağın yapısı ve biyomekanikleri değerlendirilmelidir.

\section{Diyabetik Ayak Risk Değerlendirmesi}

Anamnez ile tıbbi hikayesi ve detayl ayak muayenesi sonrası diyabetik ayak için var olan riskli durumlar saptanır. $\mathrm{Bu}$ şekilde hangi risk kategorisinde olduğu tanımlanır. Herhangi bir risk faktörü, duyu kaybı veya nabız kaybının olmadığ 1 durumlarda düşük risk, bir risk faktörünün varlığında (duyu kaybı, nabız yokluğu, kallus, deformite gibi) orta risk, eski bir ampütasyon veya ülserasyonlu ya da daha fazla risk faktörü bulunduğunda yüksek risk kategorisinde kabul edilir. Ayrıca ülserin varlı̆̆ında aktif diyabetik ayak olarak değerlendirilir. Düşük riskli olgular altı ay ya da yılda bir, orta riskli olgular üç -altı ayda bir, yüksek riskli olgular en azından aylık detaylı ayak muayenesi yapılmalıdır. Aktif ülserli diyabetik ayakta ise multidisipliner yaklaşımla hastaneye yatarak tedavi etmek gerekecektir.

Risk değerlendirmesi yapıldıktan sonra hasta ikinci kontrol için hazırlanmalıdır (Tablo 1, Ayak Risk Kategorisi, risk grupları) (20-36).

Diyabetik ayak açısından yüksek riskli hasta grupları aşağıdaki gibi sıralanabilir $(7,15)$;

- Daha önce diyabetik ayak öyküsü veya karşı ekstremitede diyabetik ülseri olanlar

- Eklem hareket kabiliyeti azalan hastalar

- Nöropati ve/veya iskemik damar hastalığ semptom ve bulguları olanlar

- Ayak deformiteleri olanlar ve uygun olmayan ayakkabı giyenler

- Ciddi görme bozukluğu olanlar

- Kötü metabolik kontrolü olanlar/kötü hijyen/kötü diyabet eğitimi olanlar

- Ayak bakımı kötü olan hastalar
Uzun süreli diğer komplikasyonları olanlar

- Alkol ve sigara alışkanlığı bulunanlar

- Yaşlı diyabetik hastalar

- Diyabet eğitimi almayan hastalar

- İlerlemiş yaş, erkek cinsiyet, düşük sosyo-ekonomik grupta olanlar.

Diyabetik ayak gelişimini önlemek ve yüksek riskli hastaların belirlenmesi ve ayak bakımı için iyi bir ayak muayenesinin dermatolojik, nörolojik, vasküler ve biyomekanik değerlendirmesi ile mümkün olabilmektedir.

\section{DIYYABET HASTASINDA PODOLOJIKK MUAYENE}

Diyabetik bireylerin ayak değerlendirmelerinde anamnez, kapsamlı ayak muayenesi bir Ayak Değerlendirme Formuna kaydedilmelidir (Tablo 1). Bu formda tibbi hikaye, cilt ve eklerinin muayenesi, ayak vasküler yapılarının muayenesi, ayağın nörolojik yapılarının muayenesi, ayağın kasları, kemikleri ve eklem yapıları ile ayakkabı uygunluğu değerlendirmelerini içermelidir. Bulgular ile risk kategorisi belirlendikten sonra tanılarına göre yapılacak işlemler belirlenir. Podolojik işlemler, verilecek tedaviler, eğitimler ve takipleri kaydedilir.

\section{Ayağın Cilt ve Eklerinin Değerlendirilmesi}

Deri, infeksiyonlara karşı bir bariyer oluşturmaktadır (37). Deri bütünlügünün bozulması, diyabetik kişileri infeksiyona açık hale getirmekte ve infeksiyonlar ekstremite kaybı, hatta ölümle sonuçlanabilmektedir. Diyabetik ayakta dermatolojik sorunların iyi gözlemlenmesi gerekmektedir $(9,38)$

Dermatojik değerlendirme bacağın ve ayağın dorsal, plantar, medial ve lateral yüzeylerinin muayenesini kapsadığg gibi ayak tırnaklarını ve parmak aralarını da kapsar.Tine pedis, ülser, maserasyon, nasır, siğil, fissür, sürtünme, kabarcık, kızarıklık ve kallus yönünden incelenmelidir $(9,39,40)$.

Hastanın her iki ayağı bilek seviyesine kadar el sırtı ile sıcaklık-soğukluk değerlendirmesi için test edilir (16). Isıda azalma arter dolaşımının yetersizliğini gösterir. Artma ise enfeksiyon belirtisidir. Sağ ve sol ayağın ilgili alanlarının sıcaklığı genellikle $1^{\circ} \mathrm{C}$ 'den fazla farklılık göstermez ve 2.2 ${ }^{\circ} \mathrm{C}$ 'den $\left(4^{\circ} \mathrm{F}\right)$ daha yüksek bir sıcaklık farkı anormal kabul edilir $(16,41)$.

Deri renginin soluk ya da siyanoze olması dolaşım yetersizliğinin, kızarık olması ise enfeksiyonun belirtisidir (27). Ayak bileğinden parmak uçlarına kadar olan bölgede deri rengi değerlendirilmelidir $(27,42)$. 
Tablo 1: Ayak değerlendirme formu.

\begin{tabular}{llll}
\hline \multicolumn{2}{l}{ Ayak Değerlendirme Formu } \\
\hline Adı Soyadı $\quad:$ & Kurum & $:$ \\
\hline T.C. Kimlik No : & Dosya/Başvuru No & $:$ \\
\hline Doğum Tarihi & $:$ & Müracaat Tarihi & $:$ \\
\hline Cinsiyeti $\quad:$ & Gönderen Birim & $:$ \\
\hline Servis Sıra No $\quad:$ & Gönderen Doktor & $:$ \\
\hline
\end{tabular}

\section{Anamnez}

Şikayeti ve Hikayesi: (....... Yaşında .... Hasta, ... Yıldır DM Tanıl, İlk .... Ayak Muayenesi)

Tıbbi Hikaye(Süresiyle Belirtiniz) Ameliyatlar (Bacak, ayak ve parmak ameliyatları) Ortez kullanımı hikayesi (Verilmiş ortez/protez)

Diabetes Mellitus, Obezite, Romatoid Artrit, Osteoartrit, Osteoporoz, Fibromiyalji, Kardiyovasküler Hastalık, Nöropati, Retinopati, Nefropati, Periferik Vasküler Hastalık, Diğer...

Aktiviteler (ayaklarla ilgili aktiviteleri sıklıklarıyla belirtiniz)

Ağrn; Gün içinde en şiddetli hissettiğiniz yeri ve şiddetini belirtiniz.

$$
\begin{array}{llllllllll}
1 & 2 & 3 & 4 & 5 & 6 & 7 & 8 & 9 & 10
\end{array}
$$

Ayaklarınızda sizi rahatsız edenleri belirtiniz.
Giyilen ayakkabılardan en rahat olanlarını belirtiniz.
Günlük ayakta durma oranı;

$\%$ 0-24 \% 25-49

$\%$ 50-74 \% 75-100

Bu değerlendirmedeki beklentiyi belirtiniz.

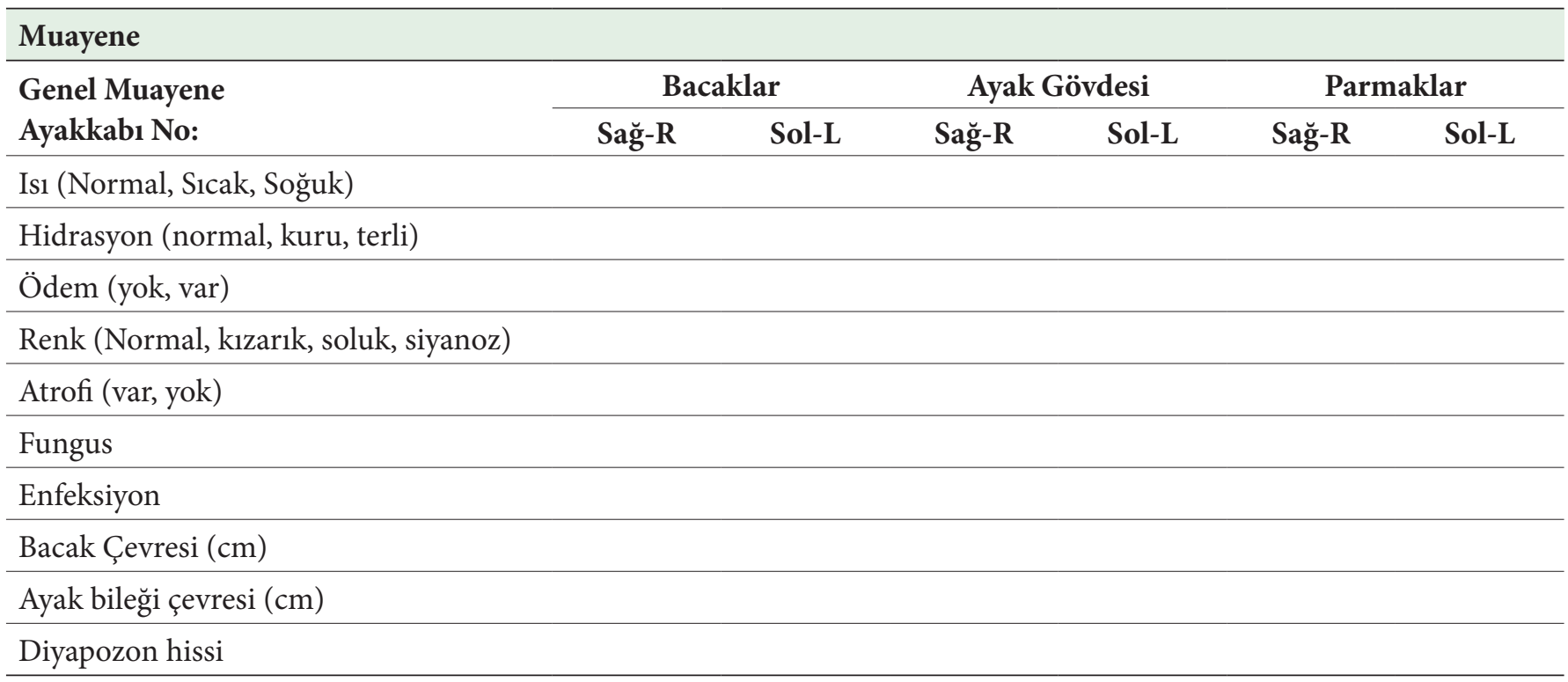


Tablo 1 devam

\begin{tabular}{lllll}
\hline Fotoğraf & & & & \\
\hline Yüz & Ayakta & Ayak Ön & Ayak Alt & Lezyon \\
\hline
\end{tabular}

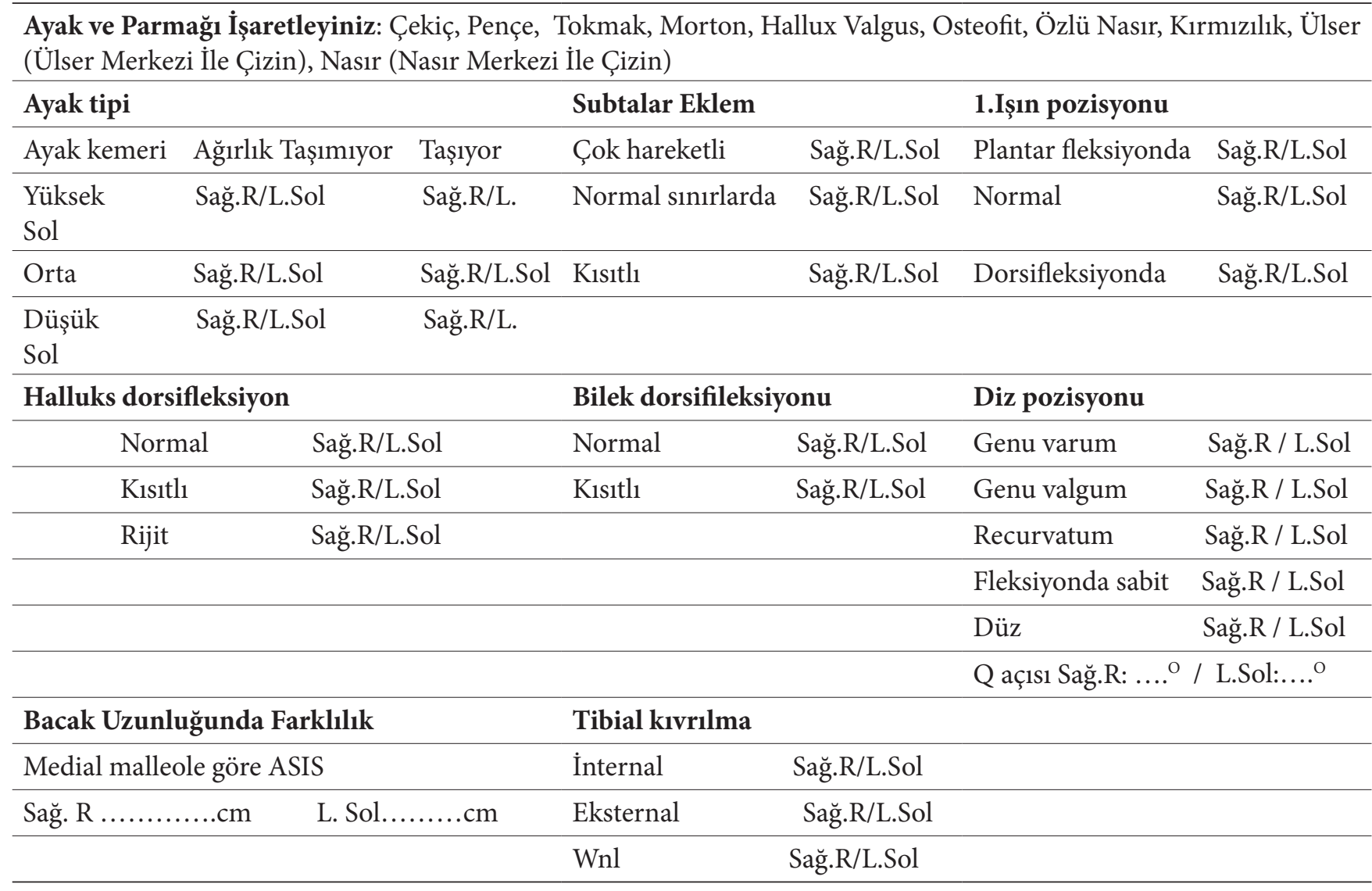

\section{Kas Gücü}

Să̆ 
Tablo 1 devam

\begin{tabular}{|c|c|c|c|}
\hline Tanı & & & \\
\hline Risk Kategori (Evet/Hayır, E/H) & Săg & Sol & Özet \\
\hline Ayakta yara hikayesi var mı? & & & \multirow{14}{*}{$\begin{array}{l}\text { Yaşında .... Hasta; .. Yakınmasıyla } \\
\text { başvurdu, } \\
\text { Muayenesinde; } \\
\text { Cilt; } \\
\text { Tırnak; } \\
\text { Venöz: } \\
\text { Arteryel: } \\
\text { Nöropati: } \\
\text { Kemik deformitesi: }\end{array}$} \\
\hline Ayakta yara var mı? & & & \\
\hline Pençe parmak var mı? & & & \\
\hline Şişlik veya ayakta bozuk görünüm var mı? & & & \\
\hline Cilt ısı artışı var mı? & & & \\
\hline Sırta doğru dorsifleksiyon kısitlı mı? & & & \\
\hline Tirnaklarda uzama - incelme - bozukluk var mı? & & & \\
\hline Kallus var mi? & & & \\
\hline Ayak ve bilekte kas güçsüzlüğü var mı? & & & \\
\hline Ayak nabızlarından birisi alınmıyor mu? & & & \\
\hline Hasta ayaklarının altını görebiliyor mu? & & & \\
\hline Ayakkabi uygun mu? & & & \\
\hline Ayak duyu noktalarında azalma var mı? & & & \\
\hline $\begin{array}{l}\text { Risk Kategorisi: O Düşük, O Orta, O Yüksek O Aktif } \\
\text { Diyabetik Ayak }\end{array}$ & & & \\
\hline
\end{tabular}

\begin{tabular}{|c|c|c|c|}
\hline \multicolumn{4}{|l|}{ Tedavi ve Öneriler } \\
\hline İleri Testler & İşlem Önerileri & Eğitim & İlaçlar \\
\hline o Mini Doppler Testi & $\begin{array}{l}\text { o Hipertrofik tırnak } \\
\text { bakımı }\end{array}$ & $\begin{array}{l}\text { o Diyabet ve Ayak Bakımı } \\
\text { Eğitimi }\end{array}$ & \multirow{8}{*}{$\begin{array}{l}\text { Sonraki Randevu } \\
\text { Tarihi:.................... }\end{array}$} \\
\hline $\begin{array}{ll}\text { o Ankle Brakial İndeksi } \\
\text { Testi }\end{array}$ & o Nasır tedavisi & $\begin{array}{ll}\text { o Ağırlığın Kontrolü, } \\
\text { yaşam tarzı değişiklikleri }\end{array}$ & \\
\hline o Biothesiometre Testi & $\begin{array}{ll}\text { o Batık Tirnak / Tirnak teli } \\
\text { tedavisi }\end{array}$ & o Ayakkabı & \\
\hline $\begin{array}{l}\text { o Diyapozon ile vibrasyon } \\
\text { testi }\end{array}$ & o Kozmetik ayak bakımı & & \\
\hline o Ayak Grafileri & $\begin{array}{l}\text { o Yürüme Değerlendirme } \\
\text { ve Egzersiz Randevusu }\end{array}$ & & \\
\hline $\begin{array}{ll}\text { o } & \text { Ayakkabı Uygunluğu } \\
& \text { Değerlendirme Formu } \\
\end{array}$ & $\begin{array}{l}\text { o Yürüme Analizi ve } \\
\text { tabanlık yapımı }\end{array}$ & & \\
\hline \multirow{2}{*}{ Konsülttasyonlar } & o Podoscanner & & \\
\hline & o Pansuman & & \\
\hline
\end{tabular}

Ödem dolaşım sorunları ya da enfeksiyonun bir belirtisidir. Diz altından ayak sırtına kadar olan bölgede ödem olup olmadığı değerlendirilerek kaydedilir. Deride terleme kaybı nedeniyle kuruluk olabilir. Terlemenin kaybı da periferik sinirlerdeki otonomik tutulumun belirtisidir $(27,42)$.
Bası ülserlerinin en önemli nedenlerinden biri deformitelere bağlı olarak basınç alanlarının değişmesidir (43). Basıncın arttığ kanaması, deride çatlak ve derin enfeksiyon (osteomiyelit) meydana gelir (7). Hastanın ayağında ülser varsa yeri ve büyüklüğ̈̈ değerlendirilmelidir. Wagner sınıflaması en sık kullanılandır (44). 
Ayak parmak aralarında mantar enfeksiyonu olup olmad1ğına bakılmalıdır. Tırnakların nasıl kesildiği incelenmelidir (düz-yuvarlak). Paronişi ve tırnak batması olup olmadığına bakılmalıdır. Kızarıklık, maserasyon, ülser, nasır, kallus ve bül onikomikoz, onikokriptoz (büyümüş tırnaklar), distrofi ve paronişi oluşumu varsa kaydedilmelidir (42-44).

Diyabetik ayakta sinıflama, tedavinin standardizasyonu açısından önem taşır. Ancak, ayak ülserleri için yaygın olarak kabul gören bir sinıflama sistemi henüz geliştirilememiştir. Tartışmalı yönleri olmakla birlikte, günümüzde halen kullanılmakta olan siniflamalardan en basiti WagnerMegitt sinıflamasıdır. Bu sinıflama sırasıyla yüksek riskli ayak (Evre 0), ülserli ayak (Evre 1), cilt altı dokulara yayılmış ülser, selülit ve osteomyelitli derin ülser (Evre 3), lokalize gangren (Evre 4) ve ayağı tutan yaygın gangrenden (Evre 5) oluşmaktadır $(44,60)$. Benzer şekilde PEDİS sınıflaması da yarayı perfüzyon, yüzey, derinlik, enfeksiyon ve duyu bulgularına görebeş klinik duruma göre sınıflamaktadır (Tablo 2). Amerikan Enfeksiyon Hastalıkları Konseyi'nin 2004 yılı kılavuzunda diyabetik ayak enfeksiyonları hafif (sadece subkutan dokuyla sınırlı), orta (daha geniş veya daha derin dokuları etkileyen) ve şiddetli (sistemik enfeksiyon bulguları ve metabolik bozukluğun eşlik etmesi) olarak sinıflandırılmıştır (61).

\section{Ayağın Vasküller Yapılarının Değerlendirilmesi}

Diyabetik ayak problemlerinin en önemli sonucu ayak ülseri sonrası dolaşım bozukluğu, iyileşmeyen yara ve amputasyonlardır. Yara gelişmesinin pek çok nedeni olmakla birlikte başlıca neden diyabetle ilişkili vasküler hastalık ve nöropatinin kombine etkisidir. Özellikle ayağın arteryel, lenfatik, yüzeyel ve derin venöz yapıları dikkatli değerlendirilmeli ve kaydedilmelidir. Ayak cilt renginin kızarması, cilt kıllarının kaybı, cildin incelmesi, cilt 1sısında azalma, ayak nabız yokluğu gibi vasküler hastalıkların bulgularının varlığı incelenmelidir (40-45).

En basit vasküler muayene proksimalden distale doğru ayak nabızlarının palpasyonu ile başlar. Dikkatli bir anamnez, inspeksiyon ve nabizların palpasyonu ile tanı rahatlıkla konulabilir. Palpasyonla ayak nabızlarına (dorsalis pedis ve tibialis anterior) bakılır. Nabızların kalitesine ve dolgunluğuna, ekstremitenin sıcaklığına ve rengine mutlaka dikkat edilmelidir (46-47).

Ayak ve kruriste kıllanmanın azalması, distrofik tırnak değişiklikleri vasküler bir yetmezliği işaret edebilir. Nabızları net olarak alınamayan veya nabız dolgunluğu düşük olan hastalarda diğer invaziv olmayan vasküler değerlendirme yöntemleri uygulanmalıdır. Sonografik doppler yöntemi ile arteryel ve venöz akımlar ile yapısal değerlendirmelerle objektif verilere ulaşılabilir. Bunun yanında ayak bileği/kol indeksi ve transkütanöz oksijen basıncı ölçümleri ile önemli bilgilere ulaşılabilir.

Ayak bileği kol indeksi ('ankle brachial index'/ ABI); ayak bileği arteryel basınç değerinin, kol arteryel basınç değerine oranlanması ile bulunur. Normalde ABI değeri 0,9 ile 1,1 arasında değişir. ABI oranının 0,7 ye düşmesi halinde kladikasyo, 0,4 te iskemik istirahat ağrısı, 0,1 ve 0,3 değerlerde yara iyileşme bozukluğu ve doku nekrozunun meydana geldiği bildirilmektedir (48).

Tablo 2: Diyabetik ayak değerlendirmesinde PEDIS sinıflaması.

\begin{tabular}{|c|c|c|c|c|c|c|}
\hline Evre & Perfüzyon & $\begin{array}{c}\text { Yara } \\
\text { Büiüüklüğüu }\end{array}$ & $\begin{array}{c}\text { Yara } \\
\text { Derinliği }\end{array}$ & İnfeksiyon & $\begin{array}{l}\text { Koruyucu } \\
\text { Duyu }\end{array}$ & Skor \\
\hline 1 & $\begin{array}{c}\text { Periferik arter } \\
\text { hastalığ }(\mathrm{PAH}) \\
\text { belirtisi/bulgusu yok }\end{array}$ & $<2 \mathrm{~cm}^{2}$ & $\begin{array}{l}\text { Yüzeyel } \\
\text { (Dermis ve } \\
\text { Epidermis) }\end{array}$ & $\begin{array}{c}\text { İnflamasyona ait bulgu } \\
\text { (eritem, endürasyon, duyarlılık, 1sı artışı) } \\
\text { ve pürülan akıntının olmaması }\end{array}$ & $\begin{array}{l}\text { Duyu kaybı } \\
\text { yok }\end{array}$ & 0 \\
\hline 2 & $\begin{array}{l}\text { PAH belirtisi/ } \\
\text { bulgusu var, kritik } \\
\text { iskemi yok }\end{array}$ & $>2 \mathrm{~cm}^{2}$ & $\begin{array}{l}\text { Subkütan } \\
\text { dokuyu } \\
\text { da tutmuş } \\
\text { ülser }\end{array}$ & $\begin{array}{l}\text { İki veya daha fazla eritemli alan, ancak } \\
\text { büyüklükleri } 2 \mathrm{~cm}^{2} \text { yi aşmamış ülsere lezyon, } \\
\text { infeksiyon deri ve/veya yüzeyel cilt altı doku } \\
\text { ile sınırlı, lokal veya sistemik belirti yok. }\end{array}$ & $\begin{array}{c}\text { Duyu kaybı } \\
\text { var }\end{array}$ & 1 \\
\hline 3 & $\begin{array}{l}\text { Alt ekstremitede } \\
\text { kritik iskemi }\end{array}$ & & $\begin{array}{l}\text { Fasya, kas } \\
\text { ve/veya } \\
\text { kemik } \\
\text { dokuları } \\
\text { ve eklemi } \\
\text { tutan ülser }\end{array}$ & $\begin{array}{l}2 \mathrm{~cm}^{2} \text { den büyük selülit, lenfanjit, gangren, } \\
\text { yumuşak dokuda apse ve fasya altına } \\
\text { yayılmış, kas, tendon, eklem ve/veya kemiği } \\
\text { içeren infeksiyon, sistemik inflamatuvar } \\
\text { yanıt sendromu bulguları yok. }\end{array}$ & & 2 \\
\hline 4 & & & & $\begin{array}{l}\text { Herhangi bir ayak infeksiyonu ile birlikte } \\
\text { sepsis. }\end{array}$ & & 3 \\
\hline
\end{tabular}


Transkütanöz oksijen basıncı (TcPO2) ölçümleri güvenilir yöntemler arasındadır. Normalde TcPO2 arteryel oksijen basınçlarının \%80 i dolayındadır ve genellikle $55 \mathrm{mmHg}$ nın üstündedir. Bu değerin 20-30 mmhg altına indiği durumlarda yara iyileşmesi bozulmaktadır (47-49).

\section{Ayağın Nörolojik Değerlendirmesi}

Nöropati, diyabetik ayak lezyonunun başlamasında önde gelen nedenlerdendir. Hastaneye yatırılan hastaların çoğunda çarpma, vurma, batma, yanma gibi hastaların farkına varamadıkları bir fiziksel etkenin yarayı başlattı̆̆ 1 anlaşılmıştır. Ayağın normal yapı ve fonksiyonlarının kaybı ile belli bölgelerin daima basınca maruz kalması, duyu kaybı nedeniyle tekrarlayan travmaların hissedilmemesi ülser gelişimine zemin hazırlar. Hastalar genellikle duyu kaybı nedeniyle yaralanmayı erken dönemde fark edemez ve ayakta kalmaya, yürümeye devam ederler. Bu da ilerleyici doku hasarına yol açar $(4,9,17,15,45,50)$.

Periferik nöropati motor, sensoryel ve otonomik nöropati olarak karşımıza çıkar. Sensörimotor nöropati sonucu, ağrı duyusu kaybı nedeniyle doku bütünlüğünü bozan bir minör travma, örneğin ayakkabının uygun olmaması, yanıklar, kesiler, böcek sokması gibi nedenler kolayca kronik yara gelişimini tetikler (3). Otonomik nöropati ayaktaki sempatik sinirlerde hasar olușturarak terlemeyi azaltır ve derinin kuru bir hal almasına ve çatlamalara neden olur. Bu çatlaklar enfeksiyon etkenleri için bir giriş kapısı oluşturur. Neden ne olursa olsun bir ülser geliştiğinde tanı ve tedavisi zamanında yapılmazsa çoğunlukla amputasyona kadar gidebilmektedir. Mümkün olduğunca objektif kriterlere dayalı nörolojik muayene, diyabetik ayağı korumada alınabilecek en ciddi önlemlerden birisidir. Diyabetli olgularda yüksek glukoz düzeyine uzun süreli maruz kalınması, periferal sinirlerin hasarlanmasına sebep olur. Diyabetik periferal nöropatili hastalarda özellikle alt ekstremitelerde vibrasyon, dokunma ve proprioseptif duyularda kayıplar meydana gelmektedir (1,3,9,51-53).

Koruyucu duyunun değerlendirmesi için aşağıda beş önemli test tarif edilmiştir. Bu testler şunlardır;

- 10-g monofilament (Semmes-Weinstein testi) - basınç duyusunu test eder.

- $128 \mathrm{~Hz}$ diyapazon - titreşim duyusunu test eder. Test yeri, ayak başparmağının ucudur.

- Pinpirik test - dokunma duyusundan sivri cisimleri ayırt edebilmeyi test eder. Test yeri ayak parmaklarının dorsumunda tırnağın başladığı yerin hemen proksimalidir.

- Ayak bileği refleksleri
- Titreşim algılaması eşik testi (Vibration perception threshold = VPT testing) - titreşim duyusunu ölçen diğer bir testtir. "Biothesiometre" cihazı ile ayak parmak ucundan ölçülür. VPT >25 testin anormal olduğunu gösterir.

S1klıkla 10-g monofilaman testi ile diğer testlerden yalnız birini uygulamak yeterlidir. Bir ya da birden fazla testin pozitif olması periferik nöropati olduğunu, iki testin negatif olması periferik nöropati olmadığını gösterir (42,52-54).

Semmes-Weinstein Monoflament Testi: Periferik sinir harabiyeti nedeniyle oluşan basınç duyusu kaybı "SemmesWeinstein" monoflamentleri ile değerlendirilir. Ayağa $10 \mathrm{~g}$ basınç veren bu filamentle yapılan değerlendirmede duyu kaybı varsa, hastanın ayağ duyusu kaybolmuştur. Bu testte kullanılan 5,07 naylon monoflament, $10 \mathrm{~g}$ kuvvet uygulandığında eğilecek şekilde üretilmiştir. $\mathrm{Bu}$ basınç, ayağın plantar ve dorsalinde yer alan belirli noktalara uygulanır. Monoflament $10 \mathrm{~g}$ kullanımı ilk olarak hastaya farklı bir alanda kullanılarak (örneğin üst kol) gösterilmelidir. Ayağa uygulanırken hastadan gözlerini kapatması istenir. Monoflament 10 gram basınç uygulayacak şekilde ( $\mathrm{C}$ harfi görünümüne gelene kadar) ayağın belirlenen alanlarına dokundurulur. Hastadan monoflamentin basincinı "Evet/Hayır" olarak yanıtlaması beklenir. Eğer duyu kaybı varsa bölge negatif olarak işaretlenir. $\mathrm{Bu}$ uygulama sonucu bireyin duyu kaybı olup olmadığı saptanır. Monoflamentin kalluslu alanlara uygulanmasından kaçınılmalıdır. Kalluslu bölgede bu uygulamanın yapılması hatalı değerlendirmeye yol açabilmektedir $(27,44,53)$.

Vibrasyon Eşiği: Diapozon ya da Bio/nöroteziyometre kulanılarak yapılabilir. Diapozon $(128 \mathrm{~Hz})$; vibrasyon algısını değerlendirmede kullanılır ve klinik uygulama için hem ucuz hem de kolay bir yöntemdir. Vibrasyon algisı her iki ayak başparmağı üzerinde test edilmelidir. Muayene eden kişi parmağın üzerine yerleştirdiği diapozonu tutarken hastanın vibrasyon duyusunu hissettiği an kaydedilir. Hasta titreşimi hissetmediğini söylediğinde muayene eden kişi hâlâ titreşimi algıllyorsa nöropati olarak değerlendirilir. Test sakin ve rahat bir ortamda yapılmalıdır. İlk olarak diapozon hastanın bileğine (dirsek ya da klavikulada olabilir) uygulanır. Böylelikle hasta önceden neyi deneyimleyeceğini bilir. Diapozon ayağın birinci parmak distal phalanksın dorsal tarafında kemik üzerine yerleştirilir. Sabit bir basınçla dik olarak uygulanmalıdır. Bu uygulama en az iki kez tekrarlanmalıdır. Bunlardan bir tanesi titreşim vermeden "sahte" bir uygulama olmalıdır. Böylelikle hastanın cevabı da test edilmiş olacaktır. Eğer hasta üç uygulamadan en az ikisine doğru yanıt verirse test pozitif olarak, en az ikisine yanlış cevap verirse negatif olarak (ülserasyon riski 
yüksek) değerlendirilir. Eğer hasta başparmakta vibrasyon hissetmezse test daha proksimalde (malleol, tibial tüberkül) tekrarlanır.

Bio/nöroteziyometre: Genellikle başparmağa prop uygulanarak ölçüm yapılır. Prop artan şiddette bölgeye titreşim gönderir. Hastanın titreşimi hissettiği nokta ölçüm eşiğidir. Biotezyometre 0-50 volt arasında değer gösterebilir. Genç normal bireylerde (örnek: vibrasyon algısı çok hassas olanlarda) düşük değerlerde ölçüm sağlanır. Daha yaşlılarda bioteziyometre progresif olarak yüksek değerlerde ölçüm gösterir. Biotezyometre ölçümü 30-40 volttan daha yüksek değerlerde algılanıyor ise bu kişilerde nöropatik ülser gelişim olasılığ 1 daha yüksektir.

Pinpirik Testi: Halluxun dorsal üzerinde tırnağın hemen proksimaline bir iğne ile basınç uygulanır, eğer iğnenin batışı hissedilmezse anormal test bulgusu olarak kaydedilir.

Aşil refleksi: Aşil refleksi hasta sırt üstü yatarken bacağını dizden fleksiyona alıp dış rotasyona çevirir. Refleks muayenesini yapacak kişi bir eliyle refleks çekiciyi tutarken diğer elini de hastanın ayak tabanına koyar ve ayak bileğini hafifçe dorsal fleksiyona getirip aşil tendona refleks çekici ile vurur. İkinci olarak aşil refleksi muayenesi şöyle yapılır. Muayene edilecek kişi dizlerinin üstünde yatak üzerinde durur. Hastanın ayakları yatak dışında olacak şekilde hasta pozisyonlanır. Ayak bilekleri serbest şekilde yatak dışında durur. $\mathrm{Bu}$ pozisyonda hastanın aşil tendonuna vurulur. Așil refleksi testi sırasında hastadan beklenen cevap ayak bileğinin plantar fleksiyon hareketidir. Ankle refleksin yokluğu ayak ülser risk artışı ile ilişkilidir $(27,44,53)$.

\section{Kas, Kemik ve Eklem Yapılarının Değerlendirilmesi}

Diabetes mellitusun yaşamı tehdit eden çeşitli vasküler komplikasyonlarının aksine, kas iskelet sistemi bulguları ciddi morbiditeye neden olmakta ve bu nedenle özel değerlendirmeye ihtiyaç duyulmaktadır. Ayakların dış ve iç kasları arasındaki mekanik dengede değişiklik nedeniyle motor nöropatinin kas-iskelet deformitelerine neden olduğu düşünülmektedir. Duyusal nöropati ise hastaları kemik değişikliklerinden habersiz kılarak kemik ve eklemlerin ilerleyici yıkımına yol açar. Diyabetik hastalarda kas iskelet sistemi değerlendirmesi, hareket ve kas gücü, yürüyüş ve herhangi bir ayak deformitesinin değerlendirilmesinden oluşmalıdır. Yapılan çalışmalarda diyabetiklerde kas zayıflığı, deformite ve ayak ülseri arasında bir ilişki olduğunu gösterilmiştir (54).

Kas kuvveti değerlendirilmesi; kas kuvvetinin muayenesi için hastanın dorsi fleksörlerinin, plantar fleksörlerin, invertörlerin ve evertörlerin kuvveti, hastanın ayağını normal hareket aralığında yukarı ve aşağı hareket ettirip ettiremeyeceğini ve hastanın direncin üstesinden gelip gelemeyeceğini belirlemek için ölçülmelidir.

Kas kuvveti, sıfır ile beş arasındaki sayılarla derecelendirilir:

- Kas gücü 5= Normal kas gücü,

- Kas gücü 4= Kas normal hareketini yapmakta, ancak karşı yönde bir kuvvet uygulandığında yenilebilmektedir.

- Kas gücü 3= Kas yalnızca yer çekimine karşı koyabiliyor.

- Kas gücü 2= Test edilen kas ancak yer çekimini ortadan kaldıran bir pozisyona getirildiğinde hareket edebiliyor.

- Kas gücü 1= Hasta ancak gözle görülebilen veya palpasyon ile farkedilen bir hareket vardır. Fakat bu, eklem hareketine sebep olmaz.

- Kas gücü $0=$ Tam felç

Kas kuvveti muayenesinde bazı hususlara dikkat edilmelidir. Muayenenin nasıl yapılacağ anlatılmalıdır. Kas kuvveti hastanın yaşı ve kas yapısına göre değerlendirilmelidir. Muayene sırasında kasın hareketini engelleyen ağrı, eklem deformitesi veya kas kontraktürü olup olmadığına dikkat edilmelidir (55).

Ayak deformiteleri değerlendirmesi: Kas iskelet muayenesi, deformite değerlendirmesini de kapsamaktadır. Ayaktaki motor kasların tutulumuna bağlı kas atrofilerinin oluşması sonucu diyabetik nöropatik ayakta deformiteler oluşur. Ayrıca ağrı ve duyu yokluğu kemik ve eklemlerin sürekli travmasina neden olur. $\mathrm{Bu}$ nedenle, diyabete bağlı olarak gelişen, çekiç parmak, pençe parmak, hallux valgus, hallux limitus, equnus, ön ayak ampütasyonu, diz altı amputasyon, Charcot deformitesi, düşük ayak vb. deformitelerin olup olmadığ 1 değerlendirilmelidir $(3,27,42,48,53)$.

Ayaktaki deformitelere bağlı olarak yeni gelișen yük dağılımının oluşturduğu yineleyen biyomekanik travmalar, özellikle de metatars başı yerleşimli kallus gelişimini tetikler. Kallus gelişimi, yumuşak doku hasarı ve enfeksiyonu açısından ciddi bir risk oluşturur. Kallus altındaki yumuşak dokuda zamanla kanama ve iskemiye bağlı yaralar gelişir ve tablo kronik ayak yarasina ilerler. Periferik otonom nöropatiyle nemliliğin azalmasına bağlı olarak kuruyan derideki çatlaklar ve nasırlar, bakteri girişine zemin hazırlar $(3,53,54)$.

Yineleyen biyomekanik travmalar sonucunda ortaya çıan yüzeysel yara ve enfeksiyonlar kısa zamanda derin yerleşimli apse ve osteomyelite ilerler.

Diyabetiklerde yaygin saptanan ayak deformiteleri arasında pençe parmak, çekiç parmaklar, halluks valgus ve Charcot 
artropatisi bulunmaktadır. $\mathrm{Bu}$ deformiteler sonucunda plantar basıncın arttığı noktalarda ülserasyonlar oluşabilir. İyibir değerlendirme yapılmazsa enfeksiyon ve ampütasyona yol açabilecek bir duruma neden olabilir. Ayak şeklindeki herhangi bir değişiklik, ödem, ayağın sıcaklığındaki artış, ağrı veya rahatsızlık değerlendirilmelidir.

En erken evrede inflamasyon ile karakterize olan ayak ve ayak bileği kemiklerini, eklemlerini ve yumuşak dokularını etkileyen bir durum olan Charcot ayağı, diyabetin en yıkıcı komplikasyonudur. $\mathrm{Bu}$ deformitenin varlığını belirlemek çok önemlidir. Kırmızı, sıcak, şiş ve ağrısız ayakları olan, diyabetik nöropatisi olan her hastada Charcot osteoartropatisi düşünülmelidir $(3,53,56)$.

\section{Diyabetik Hastalarda Ayak Muayenesi Sıklıkları}

Diyabetik ayak risk gruplarının belirlenmesi, hastalığın prognozunu ve hastaların hangilerinin daha yakın takibe alınmasını belirlediğinden, önem taşımaktadır. Diyabetik ayak risk kategorisinin belirlenmesi sonrası duyu kaybı, ülser, deformite varlığına göre muayene sıklıkları şu şekildedir $(3,15,58)$ :

- Duyu kaybı yok ise yılda bir kez,

- Duyu kaybı var ise 6 ayda bir kez,

- Duyu kaybı ve ülser gelişimi var ise 3 ayda bir,

- Duyu kaybı, ülser ve deformite var ise ayda bir,

- Charcot deformitesi var ise ayda bir kez ayak muayenesi yaptirmalidir

Ayakkabının Değerlendirilmesi/Ayakkabı Seçimi;

Ayağa uygun olmayan ayakkabıların kullanımı ayakta oluşan ülserin ve deformitelerin başta gelen nedenleri arasındadır $(44,57)$. Rahat ayakkabılar giymelidir. Düztabanlık, bunyon veya çekiç parmak gibi sorunlar varsa özel ayakkabı veya tabanlık gerekebilir (58). Ayakkabı ayağı tam kavramalıdır. Genişliği, boyu, yüksekliği uygun olmalıdır. Büyük ayakkabı sürtünme ile dar ayakkabı ise ekstra basınç ile yara nedeni olabilir. Ayakkabı önü sivri olmamalıdır.

\section{DIYYABETIK AYAK GELIŞIMINI ÖNLEMEK İÇİN DİKKAT EDİLMESİ GEREKEN NOKTALAR}

Sağlıklı bir diyabet eğitimi ve rutin uygulanan ayak muayenesi ile pek çok amputasyon önlenebilir. Hastanın ayakları her polikliniğe başvuruda kontrol edilmelidir.

- Deri çatlaklar, kızarıklıklar, nasırlar; tırnaklar kesimleri ve batmaları açısından kontrol edilmelidir.

- Her iki ayağın periferik nabızları palpe edilmeli; riskli gruplarda gerekirse doppler yaptırılmalıdır.
- Yilda bir kez mutlaka periferik sinir sistemi duyusal ve motor fonksiyonları açısından araştırılmalıdır.

- Ayaktaki şekil değişiklikleri bir ortopedist tarafından değerlendirilmeli, riskli hastaları saptamada pedografik yöntemlere başvurulmalıdır.

- Gerekli görülen hastalar gecikmeden diyabetik ayak konseyine yönlendirilmelidir.

- Gereğinde özel teröpatik ayakkabılar kullanılmalıdır $(5,8,15)$.

\section{AYAK BAKIMI}

Diyabetikler için ayak bakımı çok önemlidir. Yıllar sonra ayaklarındaki kan dolaşımı yavaşlar, sinirler ağrıya karşı hassasiyetini yitirebilir. Bu nedenle ayak ve parmaklardaki çarpma ve zedelenmeler hissedilmeyebilir. Düzenli olarak günlük ayak bakımı yapılarak problemler önlenebilir. Ayaktaki şekil bozukluklarının düzelmesi mümkün değildir. Ancak uygun ayakkabıların giyilmesi ve iyi bir ayak bakımı ile yaraların önüne geçilebilir (15).

Diyabetik Ayak Eğitiminde Hastaya Verilmesi Gereken Öneriler Şöyle Sıralanabilir;

- Diyabetin ayağınızı nasıl etkileyeceğini öğrenin.

- Ayak tırnaklarınızı düz olarak kesin, kenarlarını tırnak yatağına doğru kesip yuvarlamayın, derin kesmeyin.

- Çoraplarınızı her gün değiştirin, naylon yerine yün veya pamuklu çorap giyin.

- Çorabınızın dikiş yerleri kabaysa çorabın dışı içe gelecek şekilde giyinin.

- Yeni ayakkabı aldığınızda her zaman giydiğiniz çorapları giyinin ve ayakkabılarınızı kesinlikle çorapsız giymeyin.

- Ayaklarınızı yumuşak sabun ve ılık su kullanarak her gün yıkayın, ayaklarınızı suya batırmadan önce el ve dirseğinizle suyun sıcaklığını kontrol edin ve çok sıcak su kullanmayın.

- Ayaklarınızı her gün kesik, sıyrık, mantar ve olası kabarcıklar açısından kontrol edin. Gerekirse ayak tabanını görmek için ayna kullanabilirsiniz. Herhangi bir kızarıklık, su toplama, ağrı veya şişlik, nasır, ciltte sertlikler olduğunda doktorunuzla görüşün, erken tedavisini sağlayın, kendi kendinize tedavi etmeyin.

- Ayaklar yıkandıktan sonra üçüncü ile dördüncü ve dördüncü ile beşinci parmaklar arasına özen gösterin ve yumuşak bir havlu ile kurulayın.

- Her gün giyeceğiniz ayakkabıyı önceden inceleyiniz. 
Dikkat edilecek noktalar;

Ayakkabıda çivi olmamalı,

Ayakkabının içinde toz, taş gibi yabancı cisimler olmamalı,

İç tabanlık eskimiş olmamalı,

Dışı koruyucu özelliğini yitirmemeli,

Ayakkabının içi haftada bir kere sslak sabunlu bez ile silinmeli.

- Doktora gittiğinizde mutlaka ayakkabınızı ve çorabınızı çıkararak ayağınızı muayene ettirin $(15,58)$.

\section{SONUÇ}

Periferik motor nöropatinin yol açtığı pençe ayak, yüksek ayak arkı, metatarsofalangeal eklemlerde sublüksasyon, ayak basıncı artışı ve kallus oluşmasıyla bozulan ayak anatomisi ve biyomekaniğine, periferik duyusal nöropatinin neden olduğu koruyucu ağrı duyusu eksikliği de eklenerek, 1S1, mekanik travma veya yüksek basınca bağlı küçük veya büyük kronik yaralanmalar ortaya çıkabilir. Diğer metabolik dengesizlikler, görme kaybı, hareket kısıtlılığ 1 ve geçirilmiş ampütasyonlar da travmaya yatkınlığı artırır. Temizlik kurallarına ve ayak bakımına uymama ya da aşırı kilo gibi uyumsuz hasta davranışları, kronik hastalık psikolojisi ve depresyonla birleşince iyileşme daha da zorlaşır.(3)

Diyabetiklerde yaygin bir durum olan diyabetik ayak sendromu, hızlı ve kapsamlı bir değerlendirme yapılmadığg 1 sürece sıklıkla ülserasyon ve alt ekstremite ampütasyonuna yol açar. Dermatolojik, vasküler, nörolojik ve kas iskelet sistemi değerlendirmesini içeren kapsamlı bir ayak muayenesi ile diyabetik ayak gelişimi başarılı bir şekilde önlemek mümkün olabilmektedir. Bu değerlendirmeler, ülserasyon ve amputasyon sonucu ortaya çıkan ciddi komplikasyon riskini azaltmak için sıklıkla yapılmalıdır. Hasta tarafından alınan sıradan önleyici tedbirler, düzenli yapılan kendi kendine ayak muayenesi, ayakların uygun günlük hijyeni, plantar basınçları azaltmak için uygun ayakkabılar ve diyabet hastalarında ayak sağlığı uzmanları tarafından yapılan muayeneler diyabetik ayak gelişimini önlemektedir $(7,59)$.

Sonuç olarak, diyabetik ayak komplikasyonları yaygın, kompleks ve maliyetli bir hastalık olmakla beraber genel ya da alanında uzmanlaşmış kişiler tarafından koruyucu değerlendirmeler yapılarak kontrol altına alınabilmektedir. Diyabetli tüm hastaların ayakları ülser ve amputasyon açısından prodispozon faktörlerin (nöropati, vasküler hastalık ve deformiteler) varlığını değerlendirmek için yılda bir muayene edilmeli, “Ayak Değerlendirme Formu” üzerine kaydedilmeli ve hasta kayıtları arasında saklanmalıdır.

\section{KAYNAKLAR}

1. Ekim M, Ekim H. Diyabetik ayak ülserlerinde etiyoloji ve tedavi. Van Tip Dergisi. 2016;23(2): 235-241.

2. Bozkurt F, Alan B, Dayan S, Selçuk T, Aslan E, Deveci Ö. Alternative yöntemler eşliğinde takip ettiğimiz diyabetik ayak enfeksiyonlarımız. Van Tıp Dergisi. 2017;24(2): 71-77.

3. Saltoğlu N. Diyabetik ayak yarası ve enfeksiyonunun tanısı, tedavisi ve önlenmesi: Ulusal uzlaşı raporu. Klimik Dergisi. 2015; 28(Özel Sayı 1): 2-34.

4. Yazdanpanah L, Nasiri M, Adarvishi S, Literature review on the management of diabetic foot ulcer. World J Diabetes. 2015;6(1): 37-53.

5. Iraj B, Khorvash F, Ebneshahidi A, Askari G. Prevention of diabetic foot ulcer. Int J Prev Med. 2013; 4(3): 373-376.

6. Bahari R. The psychological impact of diabetic limb problems. The International Medical Journal Malaysia. 2015;14(2);14-16.

7. Açar G. Diyabetik ayakta tedavi yaklaşımları ve Wagner sınıflamasının tedaviyi yönlendirmedeki rolü. Uzmanlık Tezi. İstanbul-2006. (http://www.istanbulsaglik.gov.tr/w/ tez/pdf/genel_cerrahi/dr_k_gokhan_acar.pdf, Erişim Tarihi, 10.04.2019)

8. Arıkan Y, Kuzgun Ü, Sever C, Armağan R. Diyabetik ayak yarası olan hastalara multidisipliner yaklaşımda ortopedinin yeri. Ş.E.E.A.H. Tıp Bülteni. 2010:44;106-112.

9. Alexiadou K, Doupis J. Management of diabetic foot ulcers. Diabetes Ther. 2012; 3(1): 4.

10. Pendsey SP. Understanding diabetic foot. Int J Diabetes Dev Ctries. 2010; 30(2): 75-79.

11. Gemechu FW, Seemant FNU, Curley CA. Diabetic Foot Infections. Am Fam Physician. 2013;88(3):177-184.

12. Damir A. Diabetic foot infections. JIMSA October - December. 2011; 24(4):207-2012.

13. Uçkay I, Sanchez JA, Lew D, Lipsky BA. Diabetic foot infections: What have we learned in the last 30 years? Int J Infect Dis. 2015;40:81-91.

14. Boulton AJM. The Diabetic Foot. [Updated 2016 Oct 26]. In: Feingold KR, Anawalt B, Boyce A, et al, editors. Endotext [Internet]. South Dartmouth (MA): MDText.com, Inc.; 2000 (Available from: https://www.ncbi.nlm.nih.gov/books/ NBK409609/Accessed Date:10.04.2019)

15. Neşe AÇ, Ovayolu N. Diyabetik ayak ve bakımı. Atatürk Üniversitesi Hemşirelik Yüksekokulu Dergisi. 2006;9(2):8997.

16. Çelik S, Öztürk G. Diyabetik ayak: Risk faktörleri ve bakım. Diyabet, Obezite ve Hipertansiyonda Hemşirelik Dergisi. 2009; 1(1): 22-27.

17. Amin N, Doupis J. Diabetic foot disease: From the evaluation of the "foot at risk" to the novel diabetic ulcer treatment modalities. World J Diabetes. 2016; 7(7): 153-164.

18. Frykberg RG. Diabetic foot ulcers: Pathogenesis and management. Am Fam Physician. 2002;66(9):1655-1662. 
19. American Diabetes Association. Standards of medical care for patients with diabetes mellitus. Diabetes Care. 2003;26 Suppl $1:$ S33-50.

20. Ayanoğlu S. Diyabetik ayak hastalığına güncel yaklaşımlar. Okmeydanı Tıp Dergisi. 2015;31: 63-71.

21. Uluslu ŞC. Diyabetik ayak komplikasyonu olan ve olmayan diyabet hastalarının yaşam kalitesinin değerlendirilmesi. Yüksek lisans tezi. (https://tez.yok.gov.tr/UlusalTezMerkezi/ TezGoster?key=X-M9ZoIuIoNTj2P7iY13hcuuAO4b Pf8te5rIq9PXEmQ_ncKnlokMzQ7GrTx0qc9K,Erişim Tarihi:15.04.2019).

22. Satman İ. Diabetes mellitus: Giriş, sekonder komplikasyonlar. Türkiye Klinikleri Genel Cerrahi Özel. 2010;3 (1): 1-5.

23. Kargı E. Diyabetli hastada ayak bakımı ve koruyucu önlemler. Türkiye Klinikleri Genel Cerrahi Özel. 2010;3 (1): 83-87.

24. Gülçimen B, Ülkü S. İnsan ayağı biyomekaniğinin incelenmesi. Uludağ Üniversitesi Mühendislik-Mimarlık Fakültesi Dergisi. 2008;13(2):27-33.

25. Wu Y, Ding Y, Tanaka Y, Zhang W. Risk factors contributing to type 2 diabetes and recent advances in the treatment and prevention. Int J Med Sci. 2014;11(11):1185-1200.

26. Olgun N. Diyabetik ayak yaralarının önlenmesinde ve takibinde hemşirenin rolü. (http://www.tdhd.org/dhd_ kitap/12blm.pdf,Erişim Tarihi:15.03.2019)

27. Yüksel A. Diyabette ayak bakımı. (http://www.tdhd.org/dhd_ kitap/12blm.pdf, Erişim Tarihi:15.03.2019)

28. Singh N, Armstrong DG, Lipsky BA. Preventing foot ulcers in patients with diabetes. JAMA. 2005;293(2):217-228.

29. Nather A, Cao S, Chen JWL, Low AY. Prevention of diabetic foot complications. Singapore Med J. 2018; 59(6): 291-294.

30. Netten JJ, Price PE, Lawery LA, Rassmussen A, Soares MM, Jubiz Y, Bus SA. Prevention of foot ulcers in the at-risk patient with diabetes: A systematic review. Diabetes Metab Res Rev. 2016; 32(Suppl. 1): 84-98.

31. Armstrong DG, et al. Diabetic foot infections: Stepwise medical and surgical management. Int Wound J. 2004;1(2): 123-132.

32. Edmonds ME, et al. Managing the Diabetic Foot, Blackwell Science, Oxford 2005.(https://onlinelibrary.wiley.com/ doi/pdf/10.1002/9780470751527.fmatter, Accessed Date:15.03.2019)

33. Registered Nurses' Association of Ontario 2005. Assessment and management of foot ulcers for people with diabetes. Toronto, Canada: Registered, Nurses' Association of Ontario. (https://rnao.ca/sites/rnao-ca/files/Assessment_and_ Management_of_Foot_Ulcers_for_People_with_Diabetes_ Second_Edition1.pdf, Accessed Date:10.04.2019)

34. Baker N, et al. A user's guide to foot screening. Part 1: Peripheral neuropathy. Diabetic Foot. 2005;8(1): 28-37.

35. Browne AC, Sibbald RG. The diabetic neuropathic ulcer: An overview. Ostomy Wound Manage. 1999;45(1A Suppl):6S-20.
36. Lepäntalo M, Apelqvist J, Setacci C, Ricco JB, de Donato G, Becker F, Robert-Ebadi H, Cao P, Eckstein HH, De Rango P, Diehm N, Schmidli J, Teraa M, Moll FL, Dick F, Davies AH. Diabetic Foot. Eur J Vasc Endovasc Surg. 2011; 42(2):S60-S74.

37. Richmond J, Harris J. Immunology and skin in health and disease. Cold Spring Harb Perspect Med. 2014; 4(12): a015339.

38. Yeşil SA, Akıncı B, Demir T. Diyabetik ayak ülserlerinin tanı ve tedavisi. DEÜ Tıp Fakültesi Dergisi. 2007;21:63-70.

39. Kravitz SR, McGuire J, Shanahan SD. Physical assessment of the diabetic foot. Adv Skin Wound Care. 2003;16(2):75-77.

40. Edmonds ME, Foster AV. Diabetic foot ulcer. BMJ. 2006;332(7538): 407-410.

41. Biçer EK. Diyabetli hastalarda ayak bakım uygulamaları ve öz etkililiğin değerlendirilmesi. Doktora tezi. $2011 \quad$ (http://acikerisim.istanbul. edu.tr/bitstream/handle/123456789/29165/47821. pdf? sequence $=1$ \&isAllowed $=y$, Erişim tarihi 12.04.2019)

42. Türk Diyabet Vakfı. 7. Bölüm Diyabetin Kronik Komplikasyonları. 7-20/7-26 Diyabetik Ayak. TURKDİAB Diyabet Tanı ve Tedavi Rehberi 2019, Armoni Nüans Baskı Sanatları A.Ş, İstanbul, 2019, 119-128.

43. Şahin M. Diyabetik ayak. KSÜ Tıp Fakültesi Dergisi. 2015;10(2):82-86.

44. Çelik S, Biçer EK. Diyabetli hastalar için kapsamlı ayak muayenesi ve risk değerlendirmesi. Türkiye Klinikleri J Nurs Sci. 2016;8(1)62-70.

45. Arslan Y. Diyabetik ayak nöropatik ağrı ve yarasının tedavisinde girişimsel blokların yeri: Olgu sunumu. Düzce Tıp Fakültesi Dergisi. 2017;19(2):53-54.

46. Donroe J. Peripheral Vascular Exam. Journal of Visualized Experiments. (https://www.jove.com/scienceeducation/10122/peripheral-vascular-exam, Accessed Date, 10.04.2019)

47. Damir A. Clinical assessment of diabetic foot patient. JIMSA October - December. 2011; 24(4):199-203.

48. Gülman B. Diyabetik ayak. TOTBİD Dergisi. 2003;2:27-36.

49. Smart D, Bennett MH, Mitchell SJ. Transcutaneous oximetry, problem wounds and hyperbaric oxygen therapy. Diving Hyperb Med. 2017; 47(2): 82-87.

50. Volmer-Thole M, Lobmann R. Neuropathy and diabetic foot syndrome. Int J Mol Sci. 2016;10;17(6).

51. Terzi M, Cengiz N, Onar M. Diyabetik nöropati. O.M.Ü. Tip Dergisi. 2004;21(1): 39-49.

52. Çolak R. Diyabetik ayağın fizyopatolojisinde nöropatik ve nöro-iskemik ülserler. Turkiye Klinikleri J Endocrin-Special Topics. 2015;8(3):12-17.

53. Durakbaşa MO. Diyabetik ayak: Patogenez, klinik tablolar ve tedavileri, eş zamanlı hastalıklar. TOTBİD Dergisi. 2013; 12:464-475

54. Reyhanioğlu DA, Kara B, Şengün İ, Yıldırım G. Diyabetik nöropatide görülen biyomekanik değişiklikler. DEÜ Tip Fakültesi Dergisi. 2018;32(2): 167-172. 
55. Sherman AIS. Muscle Strength Grading. https://www.ncbi. nlm.nih.gov/books/NBK436008/, Accessed Date, 10.04.2019)

56. Kucera T, Shaikh HH, Sponer V. Charcot neuropathic arthropathy of the foot: A literature review and single-center experience. J Diabetes Res. 2016; 2016: 3207043

57. Güçhan Z, Özaydınlı EI, Demirdel S, Yüzlü V, Bek N. Ayakkabı kullanımı ile ayak deformiteleri, denge ve fonksiyonel performans arasındaki ilişkinin incelenmesi. Journal of Exercise Therapy and Rehabilitation. 2014;1(1):35-42.

58. Alkanat HÖ. Diyabetik ayak bakımı ve korunma. TOTBİD Dergisi. 2015; 14:470-474.

59. Troskot N, Duvancic T, Kolic M. Diabetic foot syndrome-dermatological point of view. Acta Clin Croat. 2013;52(1):99106.
60. TEMD Diabetes Mellitus Çalışma ve Eğitim Grubu. Diyabetik Ayak Sorunları. In Türkiye Endokrinoloji ve Metabolizma Derneği Diabetes Mellitus ve Komplikasyonlarının Tanı, Tedavi ve İzlem Kılavuzu-2018 (c) Türkiye Endokrinoloji ve Metabolizma Derneği Miki Matbaacılık San. ve Tic. Ltd. Şti.. - ANKARA ISBN: 978-605-4011-32-2,2018, sayfa 153-162. (http://temd.org.tr/admin/uploads/tbl_ kilavuz/20180814161019-2018tbl_kilavuz6c373c6010.pdf, Erişim Tarihi, 25.04.2019)

61. Demir T, Akıncı B, Yeşil S. Diyabetik ayak ülserlerinin tanı ve tedavisi. Dokuz Eylül Üniversitesi Tıp Fakültesi Dergisi. 2007;21: 63-70. 